\title{
Socjologia nie-literatury
}

Bogdan Balicki

TEKSTY DRUGIE 2021, NR 2, S. 358-374

DOI: $10.18318 /$ td.2021.2.21 | ORCID: 0000-0001-6409-928X

$\mathbf{P}$ rojekt zastosowania koncepcji Brunona Latoura do literaturoznawstwa oznacza zgodę na przyjęcie dwóch założeń. Pierwsze: literatura jest fenomenem społecznym i jako taka wymaga do jej opisu i analizy narzędzi socjologicznych. Drugie: literaturoznawstwo jako dziedzina zrzeszająca badaczy literatury jest również bytem społecznym i żeby je sensownie uprawiać, trzeba mieć jakiś pogląd na specyfikę konstruowania rzeczywistości w tej dziedzinie. Literatura i literaturoznawstwo łączą się ze sobą na wiele sposobów, choć jednocześnie pozostają obszarami rozłącznymi. Z poznawczego punktu widzenia to trudna sytuacja, bo przenikanie się tych obszarów utrudnia formułowanie jasnych procedur badawczych, a tym samym podnosi koszty transakcyjne nabywania wiedzy, jak tę naukę uprawiać. W tekście analizuję oba te obszary, tj. staram się krytycznie ocenić zastosowanie koncepcji aktora-sieci do społecznej nauki o literaturze (cześć pierwsza) oraz przyjrzeć się literaturoznawstwu jako wiązce stylów myślenia oraz produkowaniu wiedzy (część druga). Obie te obserwacje należy uczynić razem,
Bogdan Balicki - dr,

adiunkt w Instytucie

Literatury $\mathrm{i}$

Nowych Mediów

Uniwersytetu

Szczecińskiego.

Zajmuje się badaniem komunikacji,

literatury

oraz mediów

w perspektywie

konstruktywistycznej.

Publikował m.in.

w "Tekstach Drugich",

"Pamiętniku

Literackim"

oraz „Litteraria

Copernicana". 
gdyż szanse na wdrożenie (jakiejkolwiek) teorii społecznej do badań literackich są wprost proporcjonalne do teoretycznej chłonności dyscypliny. W części trzeciej bardzo krótko zarysowuję perspektywę rozwiązania pewnych trudności obszaru nauki o literaturze, proponując socjologię nie-literatury.

\section{Literatura jako sieć}

Poza pewnymi wyjątkami w zasadzie nie uprawia się dziś socjologii literatury, a przecież założenie, że za tekstem literackim stoi jakaś struktura społeczna, jest nieodzowne we wszystkich badaniach literackich. Weźmy choćby dwa mocno dziś eksplorowane pola zainteresowań: biografistykę i gender studies.

W wypadku biografistyki nieliterackie fakty społeczne sąsiadują z literaturą na równych prawach. Zdaniem Philipa Lejeune'a, znanego badacza tej dziedziny, w zasadzie należałoby zrezygnować z dystynkcji literatura/nieliteratura, i przejść do badania piśmienności'. Powód: proza biograficzna i autobiograficzna nie tylko włącza konwencję faktyczności, osłabiając konwencję fikcyjności (opowiadanie o sobie musi mieć wymiar prawdziwościowy), lecz także tematyzuje twórcę jako aktora społecznego. Tym samym twórczość staje się elementem obserwacji i siłą rzeczy pisarz, bohater biografii bądź autobiografii, jawi się jako aktor społeczny, a badacz chcący przyjrzeć się narracji (auto)biograficznej musi uwzględnić czynniki pozaliterackie, czasem wręcz zostać badaczem społecznym. Musi badać dokumenty, archiwa, prowadzić wywiady - podążać za aktorem, jak powiedziałby Latour.

W wypadku gender studies sprawa jest jeszcze bardziej oczywista. Analiza tekstu literackiego służy tu wykazaniu, że jest on medium lub katalizatorem konstruowania kulturowego (społecznego) obrazu płci i ról płciowych. Przedstawiciel tego nurtu staje się archeologiem i śledczym, tropiącym narracyjne formy oswajania płci i odmienności w zakresie konstruowania jej szerokiego obrazu. Tu literaturoznawstwo bardzo mocno wychyla się z bezpiecznego archipelagu tekstowości, a badacz staje się nie tylko badaczem społecznym, lecz także uczestnikiem społecznej przestrzeni negocjacji. To nie przypadek, że właśnie ta część studiów literackich bywa tematem debaty politycznej.

Tymczasem socjologia literatury od zarania pozostaje niezmiennie na literaturoznawczej ławce rezerwowej. W 1980 roku Victor Žmegač pisał:

1 Zob. P. Lejeune Napisać swoje życie. Droga od paktu autobiograficznego do dziedzictwa biograficznego, przeł. A. Słowik, M. Sakwerda, Wydawnictwo Naukowe Dolnośląskiej Szkoły Wyższej, Wrocław 2017; P. Lejeunne, M. Rodak Laboratorium badacza, "Teksty Drugie” 2018 nr 6. 
Pewność, z jaką się czasem używa terminu „socjologia literatury”, nie jest uzasadniona. Czyni to wrażenie, że mówi się o całościowej treściowo i metodologicznie zdefiniowanej dyscyplinie naukowej. Jeśli jednak zagłębimy się w teorię i praktykę badań, szybko dojdziemy do wniosku, że nazwa ta nie jest następstwem ogólnego porozumienia co do charakteru przedmiotu, ale wyrazem prowizorycznej potrzeby, aby sprowadzić do wspólnej nazwy różnorodne, nawet słabo ze sobą związane tendencje $\mathrm{w}$ badaniu literatury. W pewnym sensie więc nazwa wyprzedziła stan rzeczy. ${ }^{2}$

Oczywiście znajdziemy licznych badaczy, także współcześnie ${ }^{3}$, którzy się tą dziedziną w sposób mniej lub bardziej systematyczny zajmują ${ }^{4}$, niemniej na rynku narzędzi badawczych istnieją w zasadzie tylko dwie kompleksowe koncepcje oferujące słownik i metody zaprojektowane jako narzędzia socjologicznej analizy zjawisk kojarzonych z literaturą. Mam na myśli projekt empirycznego literaturoznawstwa Siegfireda J. Schmidta oraz koncepcję pola literatury Pierre'a Bourdieu. Pierwsza koncepcja, aczkolwiek znana już od dość dawna, nie znalazła wciąż adekwatnego do jej ambicji zastosowania, druga przeciwnie - trudno byłoby dziś znaleźć literaturoznawcę, który nie słyszał nazwiska tego francuskiego badacza.

Koncepcja Schmidta w zupełności spełnia kryteria, o których wspomina Žmegač: jest całościowa i bardzo solidnie przemyślana; jej podstawę stanowi koncepcja komunikacji literackiej samoorganizującej się w systemie mającym

2 V. Žmegač Problemy socjologii literatury, w: W kręgu socjologii literatury, red. A. Mencwel, PIW, Warszawa 1980, s. 252. Cyt. za: L. Stetkiewicz Szkice z „ziemi niczyjej” czyli z socjologii literatury, Wydawnictwo UMK, Toruń 2009, s. 11.

3 Nie odwołuję się tu do prac autorów wybitnie zasłużonych w tej dziedzinie, ale tak doskonale znanych, że to po prostu zbędne. Myślę rzecz jasna o historycznych osiągnięciach Stefana Żółkiewskiego, Janusza Sławińskiego, Jana Stanisława Bystronia, Janusza Lalewicza czy Henryka Markiewicza.

4 Wspomniana w przyp. 2 książka Lucyny Stetkiewicz zawiera rozdział Socjologia literatury istnieje, który przeglądowo zbiera archipelag prób podejmowanych w tym obszarze. Świetnie uzupełnia ją tekst Tomasza Kunza Kulturowa socjologia literatury - rozpoznania i propozycje, w: Kulturowa teoria literatury 2. Poetyki, problematyki, interpretacje, red. T. Walas, R. Nycz, Universitas, Kraków 2012, s. 413-438, a także tom Socjologia literatury. Antologia, red. G. Jankowicz, M. Tabaczyński, Korporacja Ha!art, Kraków 2015. Ostatnia pozycja zbiera teksty o/w nurcie socjologii literatury autorów cieszących się światową renomą. Wendy Griswold, autorka pierwszego szkicu, nazywa socjologię literatury „łże dziedziną", bo choć obiecująca, to jednak się nie rozwija. Zob. W. Griswold Najnowsze tendencje w dziedzinie socjologii literatury, tamże. 
strukturę (relacje ról w systemie) oraz granicę (konwencje literackie). Nie trzeba jej tu szerzej przybliżać, dlatego że są już na rynku nauki dostępne prace, które to robią ${ }^{5}$.

Schmidt pozostał badaczem niszowym, Bourdieu zaś wszedł na stałe do słownika naukowego. Najcenniejszą pracą w polskim obszarze językowym, która realizuje ten program, jest książka Literatura polska po roku 1980 r.w świetle teorii Pierre'a Bourdieu, sygnowana nazwiskami Grzegorza Jankowicza, Piotra Mareckiego, Alicji Palęckiej, Jana Sowy i Tomasza Warczoka ${ }^{6}$. Praca analizuje stan pola literackiego przede wszystkim z punktu widzenia społecznego osadzania współczesnych pisarzy, instytucji życia literackiego, a także rozmaitych uwikłań i ograniczeń, na które literatura natrafia.

Wspominam o tych dwóch koncepcjach przed omówieniem zastosowania koncepcji Brunona Latoura $\mathrm{z}$ dwóch powodów. Po pierwsze uważam, że koncepcje Schmidta i Bourdieu mogą być komplementarne - koncepcyjna zbieżność pojęć systemu (Schmidt) i pola literatury (Bourdieu) jest oczywista, choć wymaga nakładu pracy teoretycznej i badawczej. W obu przypadkach w centrum obserwacji pozostaje aktor bądź aktant, wraz z jego właściwościami. U Schmidta, którego interesuje konstruowanie komunikatu na podstawie oferty medialnej (tekst), uposażenie aktora to system założeń (Voraussetzungssystem) osadzający go poznawczo i komunikacyjnie, a zarazem wpinający w sieć wiedzy i kompetencji społecznych. Bourdieu umieszcza aktora w jego prywatnej otulinie, zwanej habitusem, zawierającej dostępne aktorowi kapitały (w tym wiedzę i umiejętności, a także zasoby ekonomiczne i społeczne) oraz zdolność ich operacjonalizacji.

Po drugie, obie te koncepcje stwarzają tło oceny przydatności innych koncepcji zaadaptowanych do literatury. Jest tak dlatego, że zarówno Schmidt, jak i Bourdieu wykonali już pracę teoretyczną i metodologiczną, kumulując w swoich koncepcjach zasób pojęciowy i faktograficzny, który bardzo często zawiera elementy wypracowane w archipelagu innych szkół badawczych.

5 Zob. Konstruktywizm w badaniach literackich, red. E. Kuźma, A. Skrendo, J. Madejski, Universitas, Kraków 2006; S.J. Schmidt Dlaczego empiryczne badania literackie? Dlaczego nie?, przeł. A. Zawiszewska, „Pamiętnik Literacki” 2008 z. 2; tegoż Literaturoznawstwo jako projekt interdyscyplinarny, przeł. B. Balicki, „Teksty Drugie” 2010 nr 4; B. Balicki Empiryczna Nauka o Literaturze - kierunek w badaniach literackich i szkoła naukowa, "Teksty Drugie” $2010 \mathrm{nr} 4$.

6 Literatura polska po roku 1980 r. wświetle teorii Pierre'a Bourdieu, Korporacja Ha!art, Kraków 2014. Nie przywołuję tu klasycznych prac Bourdieu, zwłaszcza tych tłumaczonych na język polski, założywszy, że są powszechnie znane. 


\subsection{Latour i literatura}

Żeby stosować styl myślowy Latoura do nauki o literaturze, trzeba zdać sobie sprawę z jego specyfiki ${ }^{7}$. Przede wszystkim nie jest to teoria socjologiczna, która na początku ustanawia siebie i opisywaną rzeczywistość, by zaraz potem stać się narzędziem badawczym. Jest to w znacznej mierze teoria krytyczna. Prace francuskiego socjologa to prowadzone z ogromną wnikliwością śledztwo, które ma wykazać, w jaki sposób naukowcy odtwarzają (wytwarzają) rzeczywistość faktów naukowych ${ }^{8}$.Z mojego, konstruktywistycznego, punktu widzenia wniosek jest oczywisty - rzeczywistość jest przez naukę konstruowana w kolejnych procesach translacji wiedzy, splecionych sieciach gry aktorów, połączeń, instytucji, heterogenicznych kłączy, uwikłania w politykę itd. Latour bierze na warsztat kolejne węzłowe pojęcia socjologii wiedzy, takie jak odkrycie naukowe, rzeczywistość, pomiar, język specjalistyczny, pojęcie naukowe, i odrzucając podręcznikową analizę logiki odkrycia naukowego, dosłownie patrzy na ręce naukowcom. Obserwuje np., jak podniesiona grudka gleby w dorzeczu Amazonii staje się nagle próbką w pedokomparatorze (szuflada z przegródkami na próbki gleby), gdzie zmienia się w szereg opisów, które wędrują dalej do zeszytu, podlegają dyskusji, ponownej obróbce, włączeniu w szerszy kontekst wiedzy geologicznej; śledzi obiegi wiedzy i ich przemiany w zasoby kapitałowe, transformowanie, mutowanie pojęć naukowych, które tworzą na końcu obraz rzeczywistości naukowej. Wszystko to, co w starej socjologii wiedzy wydawało się elementem „twardej nauki”, gdzieś nagle umyka, a Latour mimochodem zaczyna tworzyć nową metodę badania socjologicznego, znaną dziś jako teoria aktora-sieci甲. Zapomnij o rzeczywistości, mówi francuski badacz, zapomnij o społeczeństwie, o grupie, o prawdzie, o faktach - wszystko to chwilowe stabilizacje nieustannie sieciującej się rzeczywistości, która nie jest czymś, co masz pod stopami, lecz tym, z czego jesteś utkany, będąc węzłem w nieskończonej pajęczynie powiązań między innymi węzłami: aktorami (ludzkimi bądź nie), instytucjami,

7 Na wstępie wypada zaznaczyć, że takie próby były już czynione, zob. A.F. Kola ANT-ologia literatury, "Przegląd Kulturoznawczy” 2013 nr 1; P. Bohuszewicz Nowożytność, kontekst, pedokomparator, czyli o trzech sposobach na wyjście z getta, "Prace Literaturoznawcze” 2015, r. 3.

8 Zob. przede wszystkim B. Latour Nadzieja Pandory. Eseje o rzeczywistości wstudiach nad naukg, przeł. K. Abriszewski i in., Wydawnictwo Naukowe UMK, Toruń 2013. aktora-sieci, przeł. K. Abriszewski, A. Derra, Universitas, Kraków 2010; K. Abriszewski Wszystko otwarte na nowo. Teoria Aktora-Sieci i filozofia kultury, Wydawnictwo Naukowe UMK, Toruń 2010; tegoż Teoria Aktora-Sieci Bruno Latoura, "Teksty Drugie” 2007 nr 1/2. 
językami, zasobami społecznymi itd. Chcąc poznawać, podążaj za tą siecią i miej odwagę pójść także tam, gdzie się nie spodziewałeś.

Latoura ochoczo przyjmą zapewne badacze, dla których badanie tekstu literackiego jest właśnie rekonstruowaniem potencjalnych nici odsyłających do innych węzłów-tekstów, do innych węzłów-aktorów, a stamtąd dalej i dalej. To dziś w zasadzie dominujący model badawczy w nowoczesnym literaturoznawstwie. Nie będzie to jednak zastosowanie odkrywcze, gdyż jest to odpowiednik znanej już doskonale metafory kłącza.

Prawdziwe wyzwanie to owocne zastosowanie go do socjologii literatury ${ }^{10}$. Problem w tym, że krytyczny walor teorii aktora-sieci, zachęcający do wyważania zamkniętych drzwi (by wspomnieć choćby wykorzystanie koncepcji aktorów nieludzkich w dyskursach ekokrytycznych), sprawia zarazem, że jest to teoria niesamodzielna. ANT-owcem (badaczem stojącym na stanowisku Action-Network Theory) można być tylko dlatego, że istnieje już potężny gmach socjologii i socjologii wiedzy, który teraz można kwestionować i różnicować.

Subwersywny charakter ANT sprawia, że część zawartych w niej propozycji, które są ożywcze dla socjologii wiedzy, w literaturoznawstwie brzmią wtórnie. Nie trzeba już bowiem zwalczać e s e n cja li z m u, skoro jest jasne, że zarówno znaczenie tekstu, jak i role aktorów w systemie (bądź polu) literatury unoszą się na sieciach rzeczywistości społecznych, są czasowo stabilne, w istocie zmienne i płynne. Dzieje się tak, ponieważ ich ontologia jest zależna od ruchomej rzeczywistości obserwatorów, którzy ją definiują. Nawet instytucjonalnie silne stabilizacje faktów literackich w systemie, np. wydanie klasyki literatury w serii Biblioteki Narodowej, nie gwarantuje zatrzymania procesu negocjacji znaczeń i zmienności funkcji tekstów, a także samych autorów.

Podobnie rzecz się ma z k o n s tru k t y w i z m e m Latoura. Niezależnie od tego, czy stanowisko konstruktywistyczne jest deklaratywnie dopuszczalne w samoświadomości badaczy literatury, jestem przekonany, że każdy, kto nie przeoczył rozwoju współczesnych trendów teoretycznoliterackich, zgodzi się z tezą zawartą w tym cytacie z Nadziei Pandory:

Wydaje się, że referencja (reference) nie jest po prostu aktem wskazywania czy sposobem utrzymywania wnętrza, materialnym gwarantem prawdziwości zdania (statement); jest raczej sposobem, w jaki utrzymujemy coś w pewnej ciągłości w serii przekształceń (transformations). Wiedza nie 
odbija rzeczywistego zewnętrznego świata, który odzwierciedla przez mimesis, raczej [odbija] rzeczywisty wewnętrzny świat, pomagając mu zapewnić spójność i ciągłość."

Językowo, tekstowo, komunikacyjnie czy narracyjnie uporządkowane oferty medialne jako części systemu komunikacji estetycznej nie odbijają prawdy o świecie lub przynajmniej nie taka jest ich funkcja. Można je uznać za przejawy komunikacji społecznej, ta zaś nie ma odbijać prawdy, ale być użyteczna (ma uspójniać obraz świata, redukować dysonanse poznawcze, konstruować tożsamość itd.), a to różnica. Powinien to być już dziś literaturoznawczy point of no return.

Za potencjalnie owocne w badaniu zjawisk literackich uważam przede wszystkim pojęcia a k to r a - s i e ci oraz tra n s l a cji. Piszę „pojęcia”, a nie „teorie”, bo nie są to klasyczne wiązki hipotez umożliwiających obserwacje, lecz raczej instrukcje czy też badawcze przewodniki, które mają ukierunkować badacza pracującego metodą etnograficzną. O ile w tradycyjnej socjologii punktem wyjścia badania zbiorowości jest siłą rzeczy jakaś forma klasyfikacji (na grupy, wspólnoty, klasy, społeczności, systemy, pola itd.), o tyle w ANT punkt ciężkości zostaje przesunięty na badanie osadzenia aktora w sieci zależności, przy czym sieć tę należy rekonstruować, zawieszając stare modele klasyfikacji. Rzeczywistość społeczna to wedle tej metafory nieskończona sieć powiązań między bytami o heterogenicznej naturze. Sieć może bowiem wiązać aktorów ludzkich, nieludzkich (narzędzie badawcze, instytucja), dostępne zasoby, siły polityczne, fakty naukowe itd.:

Zadanie nie polega już na narzucaniu jakiegoś porządku, ograniczeniu zakresu akceptowalnych czynników, pouczaniu aktorów czy dodawaniu refleksyjności ich praktyce.Używając sloganu ANT, trzeba podążać za samymi aktorami, to znaczy starać się nadążyć za nimi w szalonych niejednokrotnie innowacjach, aby się dowiedzieć, jak wygląda egzystencja zbiorowości wich rękach i jakich używali metod, by utrzymaćją w całości,jakie opisy określiłyby najlepiej nowe powiązania, które zmuszeni byli oni utworzyć. ${ }^{2}$

W praktyce badań literaturoznawczych oznaczałoby to śledzenie każdego ruchu aktora (niezależnie od roli w systemie: pisarza, czytelnika, wydawcy,

B. Latour Nadzieja Pandory, s. 90. 
krytyka itd.) na jego drodze do konstruowania faktów uznanych za literackie. Faktem literackim (efektem sprawstwa) byłoby zaś wówczas zarówno stworzenie dzieła literackiego, recenzji czy pracy krytycznej, jak i wzięcie udziału w wieczorze autorskim czy przeczytanie książki. Jednocześnie należy poszukiwać powiązań silnych i słabych, co oznacza, że nie każda pajęcza nić spowijająca działania w sieci jest równie ważna. Aktor, a więc czynnik w sieci mający atrybut sprawczości, może być jednocześnie analizowany pod względem zdolności do wykorzystania, tworzenia i zrywania powiązań w celu przeprowadzenia działania, co stanowi odpowiednik habitusu Bourdieu. Inaczej przy tym niż Bourdieu, u którego gra kapitałami jest raczej dziełem świadomej strategii ${ }^{13}$, Latour uważa, że aktor nie musi być i często nie jest świadomy sieci, które mogą go oplatać. W tym miejscu koncepcja ta zbliża się w interesujący sposób do teorii systemów społecznych Niklasa Luhmanna, w którego przekonaniu społeczeństwa wyłaniają się z komunikacji, a mający materialne ciało człowiek jest środowiskiem systemu komunikacji, w którym żyje ${ }^{14}$.

Ważnym elementem konstruującym sieć i zdolności działania aktora jest procedura translacji. Dobór terminu w tym wypadku uważam za nietrafiony, o wiele bliższe samej koncepcji byłoby bowiem pojęcie transformacji:

Przez translację rozumiemy wszystkie negocjacje, intrygi, kalkulacje, akty perswazji i przemocy, dzięki którym aktor bądź siła przyznają sobie czy też sprawiają, że zostaje im nadana władza [authority], by mówić lub działać w imieniu innego aktora albo siły. „Nasze interesy są takie same”, "rób to, co ja chcę”, „nie osiągniesz sukcesu, nie korzystając ze mnie”. Kiedykolwiek aktor mówi o "nas", dokonuje translacji innych aktorów na pojedynczą wolę, której staje się ona [translacja] duchem i rzecznikiem. Zaczyna on/a za kilku (kilkoro), a już nie za jednego. Staje się silniejszy. Rośnie. $^{15}$

13 Badanie będące podstawą raportu Literatura polska po 1989 roku w świetle teorii Pierre'a Bourdieu opiera się w dużej mierze na analizie deklaratywnej, a więc świadomej wiedzy aktorów w polu literatury.

14 Zob. N. Luhmann Systemy społeczne. Zarys ogólnej teorii, przeł. M. Kaczmarczyk, Nomos, Kraków 2012; tegoż Autopoieza systemów społecznych, w: Radykalny konstruktywizm. Antologia, red. B. Balicki, B. Ryż, D. Lewiński, E. Szczerbuk, Gajt, Wrocław 2010.

15 M. Callon, B. Latour Unscrewing the big Leviathan or how do actors macrostructure reality and how sociologists help them to do so, w: Advances in social theory and methodology: toward and integration of micro and macro sociologies, ed. by K. Knorr Cetina, A. Cicourel, Routledge, London 1981, cyt. za: K. Abriszewski Wszystko otwarte na nowo, s. 24. 
Przełożenie tej operacji aktora na działanie w ramach obszaru identyfikowanego jako literatura oznacza rozpoznanie zdolności do kumulowania zasobów w celu prowadzenia działania komunikacyjnego. Translacja, w odróżnieniu od np. bourdieu'owskiej gry kapitałami, może być pojęciem szerszym, ponieważ oznacza wykorzystanie wszystkich dostępnych połączeń, których tylko potencjalna część to kapitał czy kompetencje komunikacyjne. Translacją (transformacją) nazwiemy bowiem zarówno przetworzenie jakiegoś obszaru doświadczanej rzeczywistości w temat literacki, jak i wykorzystanie współoddziaływań sąsiedztwa innych aktorów czy siły dostępnych instytucji. Aktor (autor, krytyk, czytelnik itd.) staje się podmiotem zdolnym do używania sieci w celu przeprowadzenia działania, niezależnie od tego, co zidentyfikujemy jako ową sieć i które powiązania uznamy za silne lub słabe.

Badanie - nazwijmy to wstępnie - sieci literatury z wykorzystaniem tak obranych narzędzi wygląda na pierwszy rzut oka obiecująco, gdyż stwarza przestrzeń do nieograniczonego nadmiarem teorii obserwowania ruchów aktora i wykorzystywania dostępnych mu zasobów sieciowych w celu przeprowadzenia działań. Nieskrępowanie teorią ma w myśl tej metody pozwolić na odsłonięcie wszystkich powiązań, które dostępne teorie mogą zaślepiać, jako że siłą rzeczy każda teoria oznacza selekcję. Zalety: szansa na odkrycie nowych zależności i właściwości zjawisk literackich; wady: ryzyko popadnięcia w znaną w literaturoznawstwie od zarania metodę „życie i twórczość”.

Wydaje się, że styl myślenia ANT wprowadzony do socjologii literatury nie może być zamiennikiem jej dotychczasowego dorobku, przeciwnie, może działać tylko jako jej antytetyczne uzupełnienie. Analiza usieciowienia aktorów powinna w moim poczuciu przebiegać w obecności całej siatki pojęć socjologii literatury, a nie przy ich odrzuceniu, tym bardziej że ta propozycja niesie ze sobą wiele problemów metodologicznych.

Jednym z nich jest pojęcie aktorów nieludzkich. W tradycji socjologicznej działanie może być analizowane za pomocą takich parametrów, jak intencja, scenariusz działania, możliwość działania, skutki. Jeżeli dopuścimy w tej perspektywie sprawstwo aktorów nieludzkich - niech dla przykładu będzie takim aktorem czasopismo literackie - wówczas musimy im przypisać te atrybuty, tracąc zarazem ważne rozróżnienia; jeśli tego nie zrobimy, to nazywanie instytucji aktorem będzie mieć wymiar jedynie retoryczny.

Sama likwidacja pojęcia grup również wydaje się niemożliwa - można ją zawiesić na moment badania, ale zastosowanie ANT do socjologii literatury nie może znosić tej kategorii badawczej. Znakomitym przykładem jest choćby studium Elisabeth Long Book clubs: women and the uses of reading in everyday 
life ${ }^{16}$, w którym grupa czytelnicza jest podstawą bardzo owocnych analiz oraz perspektywą obserwacji przemian czytelnictwa w USA.

Podejście Latoura zastosowane do literatury ma, jak widać, mielizny, ale są i szanse. Dopuszczenie do analizy hipotezy niesystemowej, a więc alternatywnej wobec tradycyjnej socjologii grup, może być dobrym narzędziem do identyfikowania przemian w tym obszarze. Do pomyślenia jest np. hipoteza, że system literatury, ukształtowany w Europie w XVIII stuleciu" ${ }^{17}$, podlegał w drugiej połowie XX wieku tak licznym przekształceniom, że utraciwszy silną autonomię, jaką miał w wieku XIX, zasila dziś jedynie repertuar działań komunikacyjnych, w którym dawne reguły systemowe (granice, konwencje) stają się jednym z czynników kształtujących polimorficzną komunikację społeczną. Do pomyślenia jest, innymi słowy, hipoteza (pasożytująca na Latourze), że system przeszedł w sieć, która już nie ma granic, lecz jedynie przechowuje w sobie pamięć, ślad dawnych dystynkcji i granic systemowych. Śledząc poszczególnych aktorów, możemy dojść do wniosku, że przypisywanie tekstom kategorii fikcji bądź prawdy, walorów estetycznych lub ich braku jest drugorzędne z perspektywy czytelnika osadzonego w płynnej topografii sieci. Kariera literatury faktu i np. prozy autobiograficznej w drugiej połowie XX i w XXI wieku mogą wskazywać ten kierunek.

Wykorzystanie koncepcji aktora-sieci pozwala także mieć nadzieję na sensowne powiązanie twórczości/czytelnictwa z obszarem mediów i nowoczesnych form komunikowania. I tu bowiem można założyć, że zaszła znacząca zmiana i dawne dystynkcje mogły zaniknąć. W socjologii dyskutuje się nad zagadnieniem kulturowego omniworyzmu (wszystkożerności) ${ }^{18}$, które

16 E. Long Book clubs: women and the uses of reading in everyday life, The University of Chicago Press, London 2003; zob. także wstęp do tej książki w języku polskim: E. Long Społeczna natura czytania, przeł. M. Maryl, "Teksty Drugie” 2012 nr 6.

17 Świetnie ten proces autonomizacji opisują zarówno prace Bourdieu (Dystynkcja oraz Reguły sztuki ), jak i znakomita, wciąż zbyt mało znana w Polsce, książka Siegfrieda J. Schmidta Die Selbstorganisation des Sozialsystems Literatur im 18. Jahrhundert, Suhrkamp. Frankfurt am Main 1989. Zob. także fragment tej książki w języku polskim: S.J. Schmidt System literacki końca XVIII wieku jako samoorganizujący się system społeczny, przeł. P. Wolski, w: Konstruktywizm w badaniach literackich, s. 221-232.

Zob. R.A. Peterson Understanding audience segmentation: from elite and mass to omnivore and univore, "Poetics" 1992 no. 4; A. Warde, D. Wright, M. Gayo-Cal Understanding cultural omnivorousness: or, the myth of the cultural omnivore, "Cultural Sociology" 2007 no. 1 (2). Temat ten od dawna pojawia się także w pracach polskich badaczy, zob. m.in. Ł. Iwasiński Konsumpcja kulturowa jako manifestacja statusu: od determinizmu klasowego do wszystkożerności, „Przegląd Socjologiczny" 2005 z. 3. 
może być symptomem słabnięcia dystynktywnej funkcji kultury. Jeśli nie działają dawne dystynkcje (albo działają w jednym miejscu, a w innym nie), to powstaje pytanie, co jeszcze podtrzymuje czytelnictwo, które nie spadło przecież do zera? Dlaczego YouTube i Snapchat nie zabiły powieści? Może pod kapitalistyczną strukturą dawnego prestiżu literackiego skrywa się coś jeszcze, coś, czego nie widzieliśmy wcześniej, a w czym de facto uczestniczymy? Może literatura zdjęta z cokołu traci mniej, niżby to sugerował sentyment za XIX stuleciem? Coś się zmienia i być może odsłania w przestrzeni komunikacji społecznej.

Takich pytań nie można jednak sensownie postawić w próżni. Pisząc te słowa, miałem wrażenie, że miejsca na stabilną dyskusję naukową (tj. taką, w której kapitał uwagi poświęca się problemom, a nie dyskusjom o tożsamości dyscypliny) wcale nie ma w nadmiarze. Tomasz Kunz w artykule Kulturowa socjologia literatury, przywołanym wcześniej w przypisie, zmierza w konkluzji do nowego modelu socjologii literatury, w której nie ma już systemów, pól, grup, prestiżu, istnieje natomiast płaska sieć dyskursów i nieuprzewilejowanych obserwatorów ${ }^{19}$. Skąd jednak mamy wiedzieć, że istotnie nie ma już sensu mówić o systemach i strukturach, jeżeli na rynku nauki o literaturze jest aktualnie tylko jedna praca konsekwentnie socjologiczna?

Kunz ponadto, zanim na końcowych stronach swego opracowania zarysuje „kulturową socjologię literatury”, przez kilkanaście stron snuje opowieść o niedorozwoju socjologii literatury, rozpoczynając od... przewrotu antypozytywistycznego. Jest to zapewne dowód na to, że socjologii literatury naprawdę nie ma, a zatem dyskusja nad niekonserwatywnym podejściem do zagadnień z tej dziedziny odbędzie się, jeśli w ogóle, gdzieś pomiędzy teorią a antropologią literatury $-\mathrm{w}$ literaturoznawstwie ogólnym.

\section{Literaturoznawstwo jako sieć}

Czytając Nadzieję Pandory, której bohaterami są m.in. geologiczne narzędzia badawcze, takie jak wspomniany wcześniej pedokomparator czy topofil (narzędzie standaryzujące opis właściwości gleby), których efekty zastosowania (klasyfikacja) zasilają następnie sieć naukowych działań, zadałem sobie pytanie, czy literaturoznawstwo dysponuje ich odpowiednikami. Dokładniej rzecz ujmując, pytanie to jest podwójne: czy literaturoznawcy dysponują ustabilizowaną, jak narzędziownik geologa, aparaturą badawczą pozwalającą 
im kontrolować zbieranie i opracowywanie materiału, oraz czy dyskurs literaturoznawczy (sieć) jest zdolny do ich wykorzystania w celu produkowania faktów naukowych? Na pierwsze pytanie można odpowiedzieć twierdząco: w literaturoznawstwie występują narzędzia pozwalające na operację zbliżoną do próbkowania. Metodologie badań literackich dysponują bowiem m.in. narzędziami językoznawczymi, narratologicznymi, a nawet psychoanalitycznymi, które mogą stanowić taki ekwiwalent. Drugie pytanie jest bardziej kłopotliwe; moja intuicja, wsparta na zawodowym osadzeniu w dyskursie literaturoznawczym, kazała mi wątpić w zdolność tej dyscypliny do produkcji faktów naukowych. Żeby ją potwierdzić lub odrzucić, przejrzałem dwa roczniki czasopisma „Teksty Drugie” (za lata 2018 i 2017), próbując za pomocą obserwacji niesystematycznej zastosować schemat myślenia Latoura do produkcji naukowej w naszej dziedzinie ${ }^{20}$.

Efekt mojej obserwacji jest następujący: dyskurs literaturoznawczy do klasycznych procedur naukowych ma się tak, jak teoria aktora-sieci do tradycyjnej socjologii wiedzy - jest to stosunek subwersywny. Dominującym gatunkiem pisarskim w naszej dziedzinie (ten tekst również spełnia to kryterium) jest esej naukowy. Teksty nie mają ustandaryzowanej struktury argumentacyjnej, autorzy rzadko stawiają jasno sformułowane hipotezy badawcze bądź wcale tego nie robią. Trudno wydobyć z nich metody badawcze, brakuje też jasno sformułowanych metodologii. Bardzo często wywód na temat szczególnego problemu naukowego szybko zmienia się w refleksję filozoficzną o znacznie szerszych ambicjach. Autorzy starają się, by literaturoznawczy ogląd zjawisk był możliwie nieredukujący, mając ambicję włączania do refleksji coraz to szerszych kontekstów. Proces negocjacji znaczeń pojęć badawczych zdaje się zatrzymany tuż przed ostateczną krystalizacją. Zwraca także uwagę łatwość, z jaką badacze tworzą lub proponują nowe pojęcia, zupełnie jakby wartością każdego tekstu była wyjątkowość i niepowtarzalność.

W analizowanych numerach czasopisma znalazł się numer tematyczny „Nowa humanistyka"21, który ma funkcję podsumowującą dotychczasowy stan badań w dziedzinie. W otwierającym numer tekście Przemysław Czapliński, wskazując na dezautonomizację pola nauki, pisze:

20 Zob. B. Balicki Wuścisku rozróżnienia, czyli o tym dlaczego humanistyka niesie zagrożenia dla procesu poznawczego oraz jak ich uniknać za pomoca perspektywy konstruktywistycznej, ,Litteraria Copernicana" $2016 \mathrm{nr} 3$.

21 "Teksty Drugie" $2017 \mathrm{nr} 1$. 
Nie oznacza to jednak, że nowa humanistyka jest rezultatem rozmnożonego i zinstytucjonalizowanego oportunizmu - że tworzy ją archipelag placówek i projektów, które powstały w warunkach obniżonego kryterium ścisłości i podwyższonego zapotrzebowania na słabe teorie. Jest raczej odwrotnie: właśnie „słaba teoria” i „myśl słaba” są przejawem badawczej uczciwości, rzetelniejszego rozeznania w przedmiocie badań i procedurach analitycznych, wynikających z odmowy posiłkowania się pozorami kompletnej metody. Nikt już dzisiaj takiej metody nie wypracuje; jak pisał u progu postmodernizmu Jean-François Lyotard (1979), nauka podważyła swoje własne uprawomocnienie do ustalania powszechnych standardów prawomocności wyników naukowych. ${ }^{22}$

Dalej Czapliński przywołuje lapidarne określenie Edwina Bendyka, że humaniści uprawiają „kogniwojażerkę",lokalizując w konkluzji tej części tekstu przyczynę w przedmiocie badań:

Ryzykowna kombinacja szczodrości i kleptomanii [kogniwojażerki B.B.] wynika stąd, że semimetody są z definicji niedomknięte: stan niekompletności pomaga badaczom pozostawać w kontakcie ze zmienną płynną, niestałą - ontologią przedmiotów własnych badań, choć skazuje ich na ustawiczne zalepianie dziur. ${ }^{23}$

Latourowskie podejście do socjologii wiedzy, a także m.in. koncepcja kolektywów myślowych Ludwika Flecka ${ }^{24}$ nakazują nie zgodzić się z konkluzją Czaplińskiego. Etnograficzne badanie pracy badawczej geologów i botaników (od pobrania próblki, przez klasyfikację, negocjację, ponowne badanie, rekonstruowanie opisu, projektowanie mapy itd.), opisywane z ogromną drobiazgowością w Nadziei Pandory, skłania do jednoznacznego wniosku, że ontologia obserwowanej rzeczywistości wytwarzana jest w nauce, w jej sieciach i procesach translacji oraz że nie jest w żaden sposób pobierana z zewnątrz. Nauki (dyscypliny, subdyscypliny) są autoreferencyjne, samoodnośne, pracują na strukturze, którą same dla siebie wytwarzają, przetwarzając wyprodukowane dane. Niezależnie od tego, który konstruktywistyczny wariant

P. Czapliński Sploty, "Teksty Drugie” 2017 nr 1, S. 10.

Tamże, s. 12.

24 Zob. L. Fleck Psychosocjologia poznania naukowego. Powstanie i rozwój faktu naukowego i inne pisma z filozofii poznania, red. Z. Cackowski, S. Symotiuk, Wydawnictwo UMCS, Lublin 2006. 
przyjmiemy (sieć i pętle odniesień Latoura, kolektyw i styl myślowy Flecka czy systemy samoreferencyjne radykalnego konstruktywizmu), uznamy, że rzeczywistość zawsze jest efektem obserwacji, a nie odw ro tni e (obserwacja nie jest efektem istnienia niezależnej rzeczywistości).

\subsection{Literaturoznawca jako aktor}

Idąc tropem myśli Latoura, możemy się pokusić o wskazanie sieci, która go stwarza jako aktora. Jest zatem członkiem akademii i beneficjentem długiej tradycji filologii. Na tej nici zawieszona jest jego kariera naukowa - rozwój i zdobywanie kolejnych stopni. Z całą pewnością literaturoznawca należy też do wąskiego grona czytelników intensywnie czytających, pozostających w sieci tradycyjnego czytelnictwa, w którym książka jest głównym medium. Jest ponadto członkiem społeczności uczonych we wszystkich jej wymiarach: ekonomicznym, politycznym, medialnym i każdym innym. Jest wreszcie indywiduum o własnej sprawczości, dokonującym translacji zasobów sieciowych w dostępnych ramach. Nie ma jednego prototypu literaturoznawcy, ponieważ subdyscypliny w tej dziedzinie dzielą badaczy na historyków, krytyków literackich, teoretyków literatury, antropologów kulturowych, badaczy poetyki zorientowanych językoznawczo, teatrologów itd. Jeśli cokolwiek łączy aktorów w tym zróżnicowaniu, jest to czynnik zwany literaturą - fenomen społeczno-komunikacyjny. Akademickie zaczepienie nici literaturoznawczej powinno skłaniać ku dbałości o naukowość procedur badawczych, a te - jak wskazuje choćby tekst Czaplińskiego - zdają się literaturoznawcy programowo umykać. Być może zatem coś w sieciowym osadzeniu osłabia nić łączącą pracę literaturoznawczą ze standardami wytwarzania wiedzy w nauce? Coś, co zarazem stabilizuje literaturę, ale nie tę, która jest czytana i przeżywana poza światem prac literaturoznawczych, lecz tę, która się z pętli literaturoznawczych prac wyłania.

Stawiam hipotezę, że nicią, która utrzymuje literaturoznawcę w jego dyskursywnej normalności „niedomykania” przedmiotu badań, jest s c e n i c z n o ść. Gdy pisałem ten tekst w szczecińskiej Książnicy Pomorskiej, mimowolnie uczestniczyłem $\mathrm{w}$ festiwalu literackim ${ }^{25}$, jednym $\mathrm{z}$ wielu na kulturalnej mapie Polski. Głowiąc się nad zastosowaniem teorii aktora-sieci do literaturoznawstwa, zdałem sobie sprawę, że tym, co może strukturyzować argumentacje literaturoznawcze, jest funkcja zarazem objaśniacza, mediatora

25 "Odkrywcy Wyobraźni. Festiwal Czytania" to cykliczna impreza Książnicy Pomorskiej. 
i stand-upera, którą odsłania festiwal literacki (bądź inne wydarzenie, takie jak wieczór literacki czy audycja radiowa), a która jest zinternalizowana w formach ekspresji naukowej, nawet gdy realnej widowni nie ma. W tym drugim przypadku nić ta działa w sposób niejawny.

Sceniczna rola badacza literatury sprawia, że literatura projektowana jako byt metafizyczny, jest umocowana w swojej niedookreśloności, bo z punktu widzenia aktora na scenie istotne jest nie tyle ustalenie (konstruowanie) faktów i ich znaczenia (wartość wiedzy), ile „bycie interesującym”. Ważne jest mówienie do publiczności, a analiza doświadczenia lekturowego jest jego punktem wyjścia; sceniczna nić aktora sprawia, że nie może on w pełni podążać za językiem metodologii, gdyż ten jest siłą rzeczy hermetyczny i ekskluzywny. Na scenie przed widownią złożoną z publiczności literackiej aktor musi być erudytą, wykazywać inwencję, znajdować kontrowersje, musi być przekonujący i nie może być - to bardzo ważne - nudny. A nauka bywa nudna, jak zbieranie grudek ziemi do pedokomparatora.

Na scenie, mówiąc do publiczności, zwłaszcza gdy jest nią, jak w przypadku czasopisma literaturoznawczego, widownia złożona $\mathrm{z}$ innych aktorów o równie scenicznych ambicjach, nie należy rozstrzygać, że $p$ nie jest nie-p. Zdecydowane domknięcie przedmiotu obserwacji, wyprowadzenie jasnych wniosków ma walor kończenia dyskusji, tym samym scena musiałaby przestać działać w odniesieniu do jakiegoś zakresu tematycznego, a to jest sprzeczne z istotą sceny. Scena jest, gdy są na niej aktorzy, którzy nie przestają grać.

Komponent sceniczny, o którym tu piszę, nie jest zarazem czymś, co literaturoznawcę kompromituje. To element jego osadzenia w rzeczywistości (na zasadzie zakrzepu w chaotycznym splocie czynników), a zważywszy, jak wiele obserwacji literaturoznawcy poświęcają sami sobie, jest to element ważny i stabilny.

U podstaw tej literaturoznawczej sceniczności leży kapitał symboliczny literatury i jej rytuałów. Przez lata fenomen ten obrósł licznymi funkcjami (dystynkcja przynależności do klasy inteligencji, emblemat kapitału kulturowego, narzędzie tworzenia tożsamości zbiorowych, medium politycznego sporu itd.) i mimo że zmieniają się one z biegiem czasu, swoisty prestiż literatury trwa, a literaturoznawcy poczuwają się, nie bez racji, do podtrzymania jego potencjału, tj. reprodukcji. System nauki o literaturze podtrzymuje system literatury - badacz stwarza obiekt swojego badania.

Trudność pojawia się, gdy zechcemy w tak ustrukturyzowanym literaturoznawstwie uprawiać socjologię literatury, bo badacz z wiedzą usieciowioną 
przy użyciu narzędzi bliskich pedokomparatorowi zostaje na scenie jak Himilsbach z angielskim. Jeśli hipoteza o scenicznej nici aktora-literaturoznawcy jest słuszna, przed naukowo zaprojektowaną socjologią literatury staje problem o charakterze fundamentalnym. Czy i jak badać społeczne osadzenie fenomenów uznawanych za literackie?

\section{Co robić, czyli socjologia nie-literatury}

Z powyższych prób zastosowania myśli Latoura do socjologii literatury i literaturoznawstwa, jeśli są choćby w części trafne, wynika, że teorię aktora-sieci, a także inne elementy myśli Bruno Latoura można zastosować do badań w obszarze z etykietą „literatura”, szczególnie do obszaru socjologii literatury, wymaga to jednak osadzenia teorii aktora-sieci w kontekście funkcjonujących już modeli - jako teoria krytyczna musi się posiłkować kontekstem innych badań ${ }^{26}$. Efektywność tego zastosowania jest uzależniona od sieci społecznej, w której aktor-socjolog literatury będzie mógł działać.

Postawiłem w tekście hipotezę, że elementem społecznego usieciowienia dotychczasowego literaturoznawstwa jest jego sceniczność, która sprawia,że standardowa obserwacja literaturoznawcza ciąży ku stylowi badawczemu zaangażowanemu w reprodukcję kapitału symbolicznego literatury.

To rozumowanie prowadzi do wniosku, by w ramach dyscypliny zadbać o obszar socjologii nie-literatury (pisanej właśnie z łącznikiem), tj. obszar swoistego laboratorium, w którym - mówiąc metaforycznie - oko obserwatora nie będzie zaangażowane w reprodukowanie obiektu badań, lecz jego analizę jako zjawiska wytwarzanego na przecięciu licznych procesów psychicznych, społecznych, ekonomicznych itd. Sądzę, że pozwoli to ujrzeć

26 Należy w tym miejscu - last but no least - odnotować również kontekst pewnej debaty między polskimi socjologami, która odbyła się na łamach "Studiów Socjologicznych", gdy powstawał ten artykuł. W numerze 4 z 2019 roku ukazał się tekst Michała Kaczmarczyka An invasion of tricksters. Critical remarks on Bruno Latour's social theory and its polish reception, w którym autor zakwalifikował myśl francuskiego socjologa do nurtu szkodliwego wręcz irracjonalizmu. W numerze 2 z 2020 roku tegoż periodyku na głos Kaczmarczyka odpowiedziało troje badaczy związanych z kręgiem toruńskim - Łukasz Afeltowicz, Krzysztof Pietrowicz i Radosław Sojak - tekstem Chocholi taniec. O krytyce teorii aktora-sieci w „An invasion of tricksters" Michała Kaczmarczyka, wskazując, że ANT funkcjonuje na prawach eksperymentu filozoficzno-naukowego i jako taki w pełni zasługuje na uwagę i sprawdzenie. Ten sam numer "Studiów Socjologicznych" zawiera również replikę Kaczmarczyka na odpowiedź Afeltowicza, Pietrowicza i Sojaka pt. Dyskretny urok irracjonalizmu. Dyskusja ta pokazuje, że sieciowa koncepcja Latoura sama znajduje się w sferze bardzo silnych napięć. 
większe spektrum złożoności zjawisk składających się w sumie na literaturę, także w ich fazie przedliterackiej (vide np. nieliterackie funkcje narracji czy języka figuratywnego). Można literaturę (i jej obserwatorów oraz użytkowników) obserwować jako zjawisko naturalne, wraz z wykorzystaniem wszystkich dostępnych na rynku badawczym metod i pomysłów. Właśnie taki zysk, przy całym krytycyzmie wyrażonym wyżej, widzę w dyskusji o zastosowaniu metody Latoura do nauki o literaturze.

\section{Abstract}

\section{Bogdan Balicki}

UNIVERSITY OF SZCZECIN

The Sociology of Non-Literature

Balicki presents a critical take on the application of Bruno Latour's action-network theory to literary studies. He begins by discussing methodological challenges in the context of existing studies in the sociology of literature. He then applies Latour's concept to literary studies, demonstrating that one element in the network of literary studies - a network that also appears on the surface of the text - is its scenic character. This unique aspect of the world of literary scholarship allows Balicki to conclude that research on literature ought to be expanded to include the sociology of non-literature, which situates the researcher beyond the game in which the symbolic capital in the field of literature is at stake.

\section{Keywords}

sociology of literature, literary studies, action-network theory, constructivism 